DOI: 10.46400/uygur.920400

\title{
ABDULLA TUKAY VE YENİ UYGUR EDEBIYATI*
}

\author{
[Çeviri-Aktarma / Translation]
}

Ibrahim MUTI

Akt. Gülşah EREN**

Geliş Tarihi: 19.04.2021

Kabul Tarihi: 12.06.2021

$\ddot{O} z$

Bu yazı Tatar Kültür Araștırmaları Derneği tarafından düzenlenen "Abdulla Tukay'ı Doğumunun 100.yılında Anma Toplantısı"nda Uygur aydını İbrahim Muti tarafından bildiri olarak sunulmuştur. İbrahim Muti Uygur dili ve kültürü alanında çalışmalar yapmış bir âlimdir. Muti, 1920-2010 yılları arasında yaşamış ve ceditçilik hareketinin etkisinde yetişmiştir. Dil ve kültür üzerine akademisyenlik görevinde bulunmuş olan âlimin alanında yazıları mevcuttur.

Ibrahim Muti toplantının anlam ve önemine binaen Abdulla Tukay'ın ideolojisini tanıtarak konuşmasına başlamıştır. Onun düşünce tarzını şiirleriyle aktardığını ve bu sayede diğer uluslara ulaştırdığını karşılaştırmalı örneklerle kanıtlamıștır. Klasik edebiyattan Çağdaş dünya edebiyatına geçerken aydınlar cehalete, eğitimsizliğe, hurafeciliğe karșı akımlarla eserler vermişler ve bu șekilde iletişim kurmuşlardır. İște İbrahim Muti de bu ideolojinin öncülerinden olan Abdulla Tukay'ın Çağdaş Uygur edebiyatında yeni bir edebiyat ve düşünce düzeninin oluşmasını sağladığını anlatır. Tukay'ın şiirlerinin okutulduğu okullarda yetişen Uygur gençlerinin, geleceğin yenilikçi aydınları olarak yetiştiğini örneklerle açıklamıștır. Ayrıca Çinli, Rus gibi diğer halkların şairlerinin de Tukay'dan etkilendiğini açıklamıştır. Konuşmasının sonunda ise bu tür anma toplantılarının her milletin aydınları için yapılması gerektiğini, edebiyat vasıtasıyla milletler arası iletişimin güçleneceğini vurgulamıştır.

Anahtar Kelimeler: Abdulla Tukay, Şiir, Ceditçilik, Yeni Uygur Edebiyatı, Tatar Edebiyatl.

\section{ABDULLA TUKAY AND MODERN UYGHUR LITERATURE}

\begin{abstract}
This article consists of the speech given by the Uyghur intellectual Ibrahim Muti at the "Commemoration Meeting of Abdulla Tukay's 100th Birthday" organized by the Tatar Cultural Studies Association. Ibrahim Muti is a scholar who has worked in the field of Uyghur language and culture. He lived between 1920-2010 and grew up under the influence of reform. The scholar who has worked as an academic on language and culture has writings in his field.

Ibrahim Muti started his speech by introducing Abdulla Tukay's ideology based on the meaning and importance of the meeting. He proves with comparative examples that he conveyed his way of thinking with his poems and thus conveyed it to other nations. While moving from classical literature to contemporary world literature, intellectuals produced works with currents against ignorance, lack of education and superstition and communicated in this way. Here, Ibrahim Muti tells that Abdulla Tukay, who was one of the pioneers of this ideology, ensured the formation of a new literature and thought order in the Contemporary Uyghur literature. He explained with examples that Uyghur youth who were raised in schools where
\end{abstract}

\footnotetext{
${ }^{*}$ Bu yazı Tatar Kültür Araştırmaları Derneği tarafından düzenlenen "Abdulla Tukay'ı Doğumunun 100.yılında Anma Toplantısı'nda sunulmuş olup Halide Muti tarafindan İbrahim Muti'nin yazılarının toplandı̆̆ı “Uyg்urlarniñ Yéziqi ve Tili Heqqide" adlı eserde yayımlanmıştır (Milletler Neşriyati, 2013: 454-472).

${ }^{* *}$ Doktora Öğrencisi, Ege Üniversitesi, Sosyal Bilimler Enstitüsü, Türk Dili ve Lehçeleri Anabilim Dalı, e-posta: gulsaheren6@gmail.com

Orcid: 0000-0002-9741-7499
} 
Tukay's poems were taught were raised as innovative intellectuals of the future. In addition, he explained that poets of other peoples such as Chinese and Russian were also influenced by Tukay. At the end of his speech, he emphasized that such commemorative meetings should be held for the intellectuals of every nation and that international communication will be strengthened through literature.

Keywords: Abdulla Tukay, Poetry, Reform, Modern Uyghur Literature, Tatar Literature.

Abdulla Tukay'ı doğumunun 110. yılında anmak büyük ehemmiyet arz eder. Bu etkinlik çok iyi oldu. İyi oldu dememin sebebi şu ki: Her milletten çıkan böyle aydın kişileri, halkı seven, halkı için fedakârlıkla hizmet etmiş aydınlarımızı hep beraber anmak, çok önemli ve anlamlıdır. Onun için ben Tatar Kültür Araştırmaları Derneğinin düzenlediği Abdulla Tukay’ı Doğumunun 110. Yılında Anma Toplantısı'nı gönülden tebrik ediyorum.

Ben Urumçi'de Tatar okulunda eğitim aldım. Çocukluk dönemim Tukay muhitinde geçti. Tukay’ın “Ǵelibana (Galibane)” şiiri o dönemde okullarda marş olarak söylenirdi.

Gözümün açılmasına neden olan işte bu Tatar okuluydu, bu benim şansımdı. İlk okuma ve yazmayı öğrendikten sonra, Tataristan'daki Hüseyin Medresesinden (şimdiki dilimizle söylersek Maarif Enstitüsü) mezun olmuş olan Ali Efendi'nin yanında ilkokulu bitirdim.

Daha sonraki yıllarda maarif işlerine, ilmi işlere karışmamın temelinde de ilkokul çağında değerli öğretmenlerden aldığım eğitimin büyük bir rolü olmuştur.

Ali Efendi'nin eğitim verirken kullandığı esas yöntemlerden biri Tatar edebiyatını, şiirlerini, bilhassa Abdulla Tukay'ın şiirlerini bize ezberletmekti. Onun sayesinde Tukay'ın birçok şiirini ezbere okuyabilirim. Bu șiirlerin ruhu benim ilme, fenne, yeniliklere adım atmama ilham olmuştu, bunun içindir ki Abdulla Tukay çocukluğumdaki manevi üstadımdır. Onun şiirleri bende edebiyata karşı merak uyandırmıștı. Bu okul bana edebiyatı öğreten ilk okulumdu. Ben bugün burada "Abdulla Tukay ve Yeni Uygur Edebiyatı" başlı̆̆ altında birkaç şey söylemek istiyorum.

Tukay'ın zamanında Tataristan'da bir fikir akımı vardı. Bu fikir akımı Kayyum Nasiri, Şehabeddin Mercani, Rızaeddin Bin Fahreddin gibi marifetli âlimlerle 19.yy.'nn sonunda başlayan bir akım idi. Bu akımı "Marifetçilik akımı" diye adlandırmışlardı. Marifetçilik akımı, Tatar edebiyatında, bilhassa Abdulla Tukay'ın eserlerinde ilk yansıtılan akım idi. Orta Çağdaki cehalete, cahilliğe ve hurafeye karşı yenilikler getiren marifetçilik akımı idi ve söz konusu akım Abdulla Tukay'ın benimsediği temel fikir akımı idi. Marifetçilik ideolojisi Abdulla Tukay'ın ideolojisindeki büyük bir yükseliş aşamasıdır.

Abdulla Tukay'ın şiirlerindeki ikinci akım ise "halkçılık", yani halkın menfaati için çalışma akımıdır. Halkının istikbali için kaygılanma, halkı için kederlenme ideolojisi, Abdulla Tukay'ın fikir dünyasında büyük yer kaplar. Bu iki ideolojiyi bizim memlekete getiren Abdulla Tukay'dı!

Uygur klasik edebiyatından çağdaş edebiyata geçerken, şairlerimizden bu yolda yürüyenlerin hemen hemen hepsi Marifetçilik akımının yolunu tutmuşlardır. Biz buna "halkı aydınlatma akımı" dedik (Uygur Aydınlatma Derneği dedik)! Halka hizmet etme, halkın kederine ortak olma fikir akımını Abdulla Tukay'ın şiirlerinin tesiriyle Uygur edebiyatına getiren şairlerden biri Abdulhalik Uygur'dur.

Abdulhalik Uygur'un eserlerine iyice göz atarsak, onun eserinde Abdulla Tukay'ın tesirinin çok güçlü olduğu görülür. Abdulhalik Uygur'un eserlerindeki yeni maarif, maarifetçilik fikri kimden geldi? Tukay'dan geldi. Uygur halkı için kaygılanma, kaderini düşünme fikri Abdulla Tukay sayesinde Uygur edebiyatına girdi. Bu iki fikir Tataristan'da başladı, sonra 
bütün Orta Asya'da, Özbek, Kazak ve bunun gibi halkların yeni medeniyete adım atmasında temel ideoloji oldu. İște bu akımlar Abdulla Tukay'ın şiirleri sayesinde bizim Abduhalik Uygur'un şiirlerinde de yansımasını bulmuştur. Abdulla Tukay'ın şiirlerindeki eski toplumu, cehaleti, hurafeleri eleștiri, Abduhalik Uygur'un şiirlerinde ve bütün Uygur şiirinde yansımasını bulmuştur.

Aşağıda Tukay'ın ${ }^{1}$ bir şiiri ile Abduhalik Uygur²'un bir şiirini bu bağlamda okumaya çalışalım:

\section{BİZNIÑ ORUNSIZ YAMANLİLAR}

Sadaqet bizde yokmış bolmasa yalġanımız bardır,

Nifaq vistafkasında köp médal alganımız bardır.

Nezafetke regiayet yoq imiş bizde, ne bohtandur,

Anñıçun yurt sayin bizniñ birer qumġanımız bardır.

\section{BİZİ HAKSIZCA KÖTÜLÜYORLAR}

Sadakat yokmuş bizde, olmasın, yalanımız vardır;

Nifak sergisinde çok madalya alanlarımız vardır.

Nezaketen riayet yokmuş bizde. $\mathrm{Ne}$ iftiradır!

Onun için her evde birer leğenimiz vardır.

Taġın bizde ġılım ehli - ziyalıylarda yoq diler, Hatta bizde âlimler, aydınlar da yok, derler;

Otız yıllap boxar, qargalıda turganımız bardır 30 yıl Buhara'da, Kargalıda kalmamız vardır.

Tatarda acça yoq, baylıqta yoq dip yoqnı söyliler,

Oram tolı, qolın ceyip burç surġanımız bardır.

Sanaġet yoq, hüner yoq dep yamanlilar ornısızga,

Yehudiden ciñil mal tapquçı işanımız bardır.
Tatarda para, zenginlik yok, diye, yalan söylerler;

Sokaklar dolusu el uzatıp dilenen dilenenlerimiz vardır.

Sanat yok, hüner yok, diye yersizce kötülüyorlar,

Yahudi'den daha kolay mal alan şeyhlerimiz vardır.

1 Yazıda yer alan Abdulla Tukay şiirlerinin Türkiye Türkçesi'ne aktarılmış halleri Fatma Özkan'ın doktora tezinden edinilmiștir (Özkan, 1994).

2 Abduhalik Uygur'un şiirinin Türkiye Türkçesi'ne aktarılmış hali Alimcan İnayet'in eserinden edinilmiştir (İnayet, 2007). 
Zakon bilgen yorist yoq dip oylav xata hetta, Kanun ve hukukçu yok biz de derler hatta Piçen, şalqan bazarında zakon satqanımız Saman, buğday pazarlarında kanun kitabı bardır. satanlarımız vardır.

Tebiblik feni yoq dip te yamanlilar,

Tıp ilmi yok diye de kötülerler, düşmanlar, di doşmannar,

Merizlerni yasin birlen soġı yıqqanımız bardır.

Hastaları Yasin ile vurup yere serenlerimiz vardır.

Muheddis barlıġın monkir "Kofir Mühendislerin varlığını inkâr eden, "Küfür poçmaġı"na barsın, Köşesi"ne gitsin,

Korp şunda: boyın - iñin bilip qalġanımız bardır.

Görür orada: Boyunun ölçüsünü alanımız vardir.

İnanmañız birav yoqtur dirise bizde İnanmayız, biri yoktur derse bizde şairler; şaġırlar,

"Tahir"din "bozyigit"den şöbhesiz ozġanımız "Tahir"den, “Bozyiğit”ten, ş̧üphesiz bardır. geçenimiz vardır.

Oñay turmuş bolayda, hiç iymibiz baş Rahat hayat budur, hiç baş eğmeyiz yañalıqqa, yeniliğe;

Qul tırsınnar bozıq yaşler, alar: çalbarları Kudursunlar çılgın gençler, onların tardir. pantolonları dardır.

Xeram oyın - felennerden zarar times xuday qoşsa;

Haram oyun ve kumardan zarar görmeyiz, Tanrı korursa;

"Hidaya şerxi" namıda çoyın qalqanımız "Hideye Şerhi" adlı çelik kalkanımız bardir. vardir.

Alar aldarlar aldatsañ, cesör mofiti de yoq Aldanıorlar, cesur müftümüz yok, dirler, diyenler,

Mexebetli uzun boylı, Muhemmetyarımız bardir.

Sevimli, uzun boylu Muhammetyar'ımız vardir.

Xudojnıklar ve ressamlar da bardır, yoq Sanatçımız, ressamımız da vardır, yok diyalmaslar, diyemezler:

Medine, Mekke de, turlı boyav satqanımız bardır.

"Medine, Mekke" resimleri satanlarımız vardır. 
Cirenmeslik mosafirxane hem așhane yoq, Birinci sınıf otel ve lokantalarımızı yok, diler, derler,

"Sarayi"dan çiştalıqta kim togil "Bolġar"ımız bardır.

"Saray"dan daha temiz "Bulgar"1mız vardır.

Abduhalik Uygur'un șiiri:

\section{BARDUR}

Cahalet semeresidin bizge bir kün köp xata bardur,

Eytiñizçu, bügünki halimizñin qaysibiride sapa bardur

Cahanniñ halidin vaqip bolup turmaqniñ orniga,

Birini şañyu saylap arqidin devayimiz bardur.

Dostluq hem ittipaqliq nişani qalmidi bizde,

Yéñi başni kötürgenni urup yiqitqanimiz bardur.

Biri bir yaxşiliq qilsa, uniñ yadini qilmaq yoq,

İpi kelse bérip evretlirini açqanimiz bardur.

Yene yurt paydisiga cem bolmaqliq besi müşkül,

Nezir toyu ziyapetke bérip yatqanimiz bardur.

Xataen dostimizda bir eyib zahir bolup qalsa,

Yoşurmay birge onni qoşup çaqqanimiz Değil örtmek, bire on sayışımız vardır. bardur.

\section{VARDIR}

Cehalet semeresinden bize bir gün çok cefa vardır

Söyleyin, bugünkü halimizin neresinde sefa vardır.

Dünya halinden haberdar olmanın yerine

Birini muhtar seçip ardından davamız vardır.

Kardeşlik ve biraderlik nişanı kalmadı bizde

Dost görünsek de, aslında başka niyetimiz vardir.

Bir insan bir iyilik etse, değil onu yâd etmek

Fırsat olsa gidip avretini açtı̆̆ımız vardır.

Üstelik yurt yararına toplanmak hiç de kolay değil

Eğer bir yerde dügün varsa gidip yattığımız vardır.

Yanlışlıkla dostumuzda bir kusur zahir olsa

Kéreksiz mustehep işlar üçün canni pida Gereksiz işler için canı feda etmekten 
qilduq,

Ve lékin hecge bac alsa tozup qaçqanimiz bardur.

İlimniñ ictihadiġa köñülni qoymuduq bizler,

Oqurmiz - oquturmiz dep ségiiz çaynaşimiz bardur.

Oyun - çaqçaq tüpeyli dostlar ara biep bolup qalsaq,

Yaraşturup qoyuş yoq, arigia ot yaqqanimiz bardur.

Xuşamet babida bizdin bolek ustisi kemdur, Dalkavukluk etmede bizim üstümüze

Quvlugiuşumluq bilen reñmureñ yalġanimiz bardur.

İlim - penge yürüş qilgaan uçar kökte, üzer İlim yolunda giden uçar gökte, yüzer suda suda,

Minişke qotur éşek yoq yayaq qalganimiz bardur.

Gürkirep kelse aptomobil "néme bu ey xudayim" dep,

Eqlini işlitelmey hañ - tañ kélipqaçqanimiz bardur.

Bovaylar geyritini, şöhritini héç Atalarının şöhretini, gayretini hiç anmayız séginmaymiz,

Qélip gepletcahalette yumup köz po atqanimiz bardur.

Hüner bilen sanaette yétiştuq boldi iş pütti, Hüner ve sanayide "yetişkin" artık iş bitti Umaç içmekke xumdanda hécir qoyġanimiz Yahni içmeye fırında tas yaptığımız vardır. bardur. yoktur

kaçmayız da

Hacca vergi alınsa toz olup kaçtığımız vardır.

İlim öğrenmeye fazla gönül vermedik bizler

Okuruz okuturuz diye sakız çiğneyişimiz vardır.

Oyun, şaka nedeniyle kendi aramızda kavga olsa

Değil barıștırmak, ateşi körüklediğimiz vardır.

Kurnazlık etmek için türlü yalanımız vardır.

Binmeye eșek bile yok yayan kaldığımız vardır.

Gürültüyle gelse otomobil nedir bu Allah'ım diye

Aklı hiç kullanmadan şaşıp kaldığımız vardır. da

Cehalette gözü yumup havadan attığımız vardır. 
Teavunu-tenasöz orniga bizlerde bir adet,

Bilimge saye qilġanni tépip qalġanimiz Başını kaldıranı vurup yıktığımız vardır. bardur.

"İt urganini tonur" dep bar idi bir zerrin mesel,

Loyi, ambal, darénni sémiz baqqanimiz bardur.

Muneccim hem injénér alimlerniñ orniġa,

Tonur selle, nepsi bala mollimiz - sultanimiz bardur.

Qizil közlük körelmeslik veya öz qilalmasliq,

Qilay dep bel baġliganlarg̉a türlük tümen bohtanimiz bardur.

El-yurtniñ derdige qilçe derman bolmuduq bizler,

Kélür bir kün aşu çaġda ornigakelmes puştaymanimiz bardur.
"Köpek döveni tanır" diye vardır bir atasözü

Ağam, kaymakam, beyim diye iyi baktığımız vardır.

Astronot, mühendis ve âlimlerin yerine

Cübbeli sarıklı açgözlü molla sultanımız vardır.

Kurnazlık, çekememezlik veya beceriksizlik

Yaparım diye niyetlenenlere türlü iftiramız vardır.

İlin yurdun derdine hiç derman olmadık bizler

Bir gün gelir o zaman çok çok pişmanımız vardır.

Abdulhalik Uygur'un şiirlerinin veznine bakın, Tukay'ınkini tekrarlıyor, "almışlığımız vardır; kaçmışlığımız vardır; satmışlığımız vardır" denen şekilde. Demek ki Abduhalik Uygur, Tukay'ın şiirinin şeklinden faydalanıp Turfan'da bu şiiri yazmış ve Turfan'daki kötülükleri ifşa etmiştir. Bu şiir yalnız konu bakımından değil, şekil bakımından da Tukay'ınkini hatırlatıyor. Demek ki Abduhalik Uygur, Tukay'ın ideolojisini de benimsemiştir. Tukay'ın şiirlerindeki birkaç meziyetten de faydalanmıștır. Bu şiirde Tukay mollaları sertçe azarlıyor:

Közin yomġan, moyin bükken, başında çalma çornalġan,

Kiben çalma kibek başta: İşan

Bolġan imiş xayvan!
Gözünü yummuş, boynu bükük, başında sarı̆̆ı var,

Hasır sarık, kepekli kafa, meğer şeyh olmuş hayvan!

Tukay'ın mollalara yönelik bu hücumlarına Uygur edebiyatında Abdulhalik Uygur'un şiirlerinde de rastlanır. Eski toplumdaki cehalete, hurafeciliğe, molla-hocaların çirkin davranışlarına Tukay öfkeyle saldırmıştır. Abduhalik Uygur da Tukay'ı örnek alıp benzer bir eleştiri ortaya koymuştur. Hâlbuki bugünkü şairlerimizden bir babayiğit çıkıp böyle sözler edebildi mi? Biz edemedik, korkuyoruz, "hocalara, mollalara dokunursan kötü olur" diye. Aslında ifșa etmek gerek idi. Yeni Uygur edebiyatı ilk zamanlarda Abdulla Tukay'ın tesirinde, böyle bir ruha sahip olabilmiştir. Bu durumu Tukay'ın tesirinden ayrı 
düşünemeyiz. Şimdi Tukay'ın tesirine en çok uğramış olan ikinci meşhur şairimiz Lutpulla'yı konuşalım.

Lutpulla çocukluk dönemine Gulca'da, Tatar mektebinde Tukay'ın eserlerini ezberleyerek başlamıştır. Onun birçok eserini ezberlemiştir. Darülmuallim'e girdiğinde 24. , 26. sınıflarda Urumçi ve Doğu Türkistan'ın güneyinden gelen birkaç şairle okumuştur. Onların içinden birçok şairimiz çıktı. Bu iki sınıfın öğrencilerinden başta Lutpulla olmak üzere, Elkem Ehtem, Enver Nasiri, Tursun Vahidi Kızık gibi 6-7 şair yetişmiştir. Onların öğrencilik döneminde ben bu sınıflara ders vermiştim. Bir gün derse gecikmiştim. Sınıfa yaklaşınca birisinin şiir okuduğunu fark ettim. Baktım ki, Lutpulla'ymış. O "arkadaşlar öğretmenimiz İbrahim Muti gecikti. Ben size bir şiir okuyayım" deyip Tukay'ın "Kitap" adlı şiirini okumakta imiş. Bu şiir, benim çocukken ezberlediğim şiirdi, hâlâ aklımda duruyor.

\section{KİTAB}

Hiçde köñlim açilmasliq içim puşse,

Öz- özümni körelmiçe roxim tüşse.

Cefa çiksem, cüdep bitsem bu başimni,

Qoyalmiçe canġe cili héç bir tüşke.

Xesret soñre xesret qulıp almaş - almaş,

Köñilsiz öy bilen tema eylense baș.

Közlerimde kibib te citmegen bulse,

Xezirgine sığılıp - sığılıp yılaġan yaş.

Şul vaqıtta min qolıma kitab alam,

Anıñ izgi sexfelerin aqtaram.

Rexetlenip kite şundaq canım, tenim,

Şunnaġına dertlerime derdmen tabam.

Oqup barġan herbir yolım, herbir sözim,

Bola minim yol körsetköçim yoldızım.

Süymi başlim bu dunyanıñ vaqlıqların,

Açıladır, nurlanadır köñlim, közim.

Ciñlenem, meġsulenem min şul çaqta,

Rexmet, eytem uqı̇anım şul çaqta,

İşançım arta minim öz - özime,

Ümid birlen qariy başliyim bulaçaqqa.

\section{KITAP}

Gönlüm hiç açılmasa, içim sıkılsa,

Kendi kendimi göremeden, ruhum çökse,

Cefa çeksem, yorulup bitsem, şu başım

Koyamasam, cana yakın, sıcak bir göğse.

Hasret sonra, hasret gelse sira sıra,

Sıkıcı düşüncelerle tamamen dönse baş

Kurusa büsbütün akmaz olsa,

Gözlerimden durmadan dökülen yaș.

0 zaman ben, elime kitap alırım,

Onun faydalı sahifelerini karıștırırım

Huzura kavuşur o anda ruhum, bedenim,

Böylece, dertlerime derman bulurum.

Okuyarak buldum doğru yolu ve sözü,

Okumaktır, benim yol gösteren yıldızım;

Sevmemeğe başladım dünyanın küçüklüğünü

Açlmakta, nurlanmaktadır gönlüm, gözüm.

Hafiflerim, arınırım okurken,

Teșekkür ederim, okuduğum kitaba.

İtimadım artar kendi nefsime,

Ümit ile bakmağa başlarım geleceğe. 
Onların dikkatini dağıtmayayım diye dışarıda bekleyip Lutpulla şiiri okuyup bitirdikten sonra sinıfa girdim. Çocuklara "ne yapıyorsunuz?" deyince "öğretmen gecikmişti. Lutpulla, Tukay'ın bu şiirini bize okudu" diye cevap verdiler. O zamanlarda sınıftaki öğrencilerin hemen hemen hepsi Tukay'ın şiirlerini ilgiyle okuyordu, hatta Tukay'ın birkaç ibretlik şiiri çocukların ezberindeydi.

Şeñ Şisey, beni ve iki öğretmen arkadaşımı - ben, Mevlancan ve Ahuncan - bir gecede tutukladı. O zaman bu iki sınıfın çocukları öğretmensiz kaldı. Bu duruma onlar itiraz etmişler. "Neden bizim iyi öğretmenlerimizi tutuklayıp hapse atıyorlar?" deyip 4-5 öğrenci kapının önüne çıkmış. "Vali konağına gidelim, şikâyet edelim, valiye arz edelim, öğretmenlerimizi ne diye almış" dediğinde Lutpulla, "Arkadaşlar, ben sizlere Tukay'ın bir şiirini okuyayım" deyip "Kéñeş (Tavsiye)" adlı şiirin şu bu mısralarını okumuş:

\section{KÉÑES}

Yaqın dustım! Siña minnet kéñeş şul,

Kişilerge sırrıñnı süylemes bul.

İçiñde nerse yanganın öziñ bil,

Öziñ qayġır, öziñ yığla, öziñ kül.

Açıp yaşıdın xezineñni yürekten,

Süyleşme birde artıq söz kérekten.

Kişiler özlerin ançaq süyerler,

Bextsizlerniñ üstinen külerler.

Alar yırtquç, alardan çitte bul sin,

Alar barda böriñ bir yaqta torsin.

Sırriñ bilgeç, qızartirler yüziñni,

"Cöler bu!" dip açrmasler köziñni.

Qaça köz, qoş kibi, maqtavlerinna,

Xeberdar bol ki şunda au barınnan.

Eger bassa sini bir - bir zamannı,

Yılamıy, temli - temli köz yașı tök.

\section{TAVSIYY}

Yakın dostum! Sana şudur tavsiyem:

Sırrını söyleme bașkalarına.

İçinde neyin yandığını yalnız sen bil

Kendin kaygılan, kendin ağla, kendin gül.

Açma yüreğindeki gizli hazineyi

Gereksizce sarf etme bir tek kelimeyi.

İnsanlar ancak kendilerini severler,

Bedbahtların haline gülerler.

Yirtıcıdır onlar, uzak dur,

Onlarla olduğun zaman, kurdunu yanına al.

Sırrını bilirlerse, kızartırlar yüzünü,

Deli diye açtırmazlar gözünü.

Kaçıver kuş gibi, dalkavuklardan,

Haberdar ol, kurtul hepsinden.

Eğer kederlenirsen, günün birinde,

Ağlamazsan, geçmez üzüntü ve kederin. 
Utır avlaqqa, qayda hiç kişi yoq,

Sabıyday, temli-temli köz yaşı tök.

Kélip kirse birev neq şul çaqında,

Siña min bir kiñeş eytim taġında:

Digin sin: "Közlerim niktir avırta,

Üzilmi yaş ag̉a kiç hem de irte!"
Sakin, insanlardan uzak bir köşeye çekil

Çocuklar gibi tatlı tatlı gözyaşı dök

Gelip görürse seni birisi orada,

Bulunayım sana bir tavsiyede daha.

Dersin ki:"Gözlerim ağrıyor, nedense,

Durmadan yaş akmakta, gündüz ve gece!"

"Arkadaşlar bu şekilde gidersek bizi de tutuklarlar, hapsederler. Bu yüzden içimizde yanan derdi içimize atalım, Tukay'ın bu mısralarını ezberleyip, ağlayacaksak yatağımızda ağlayalım, söyleyecek sözleri odamızda söyleyelim" demiş. Demek ki Tukay'ın nasihatleri bu çocukların, bu şairlerimizin her birinin riayet ettiği ibretli sözlere dönüşmüş.

Sonra bir şey bana şaşırtıcı geldi. 1946 yıll, yani kurtuluştan önce ben Pekin'e gittim. "Hamiguen denen yerde Mamut Sican (Albay), yani Mamut Muhiti adlı kişi vefat etmiş" haberini duyduğumda, bu kişinin yaşadığı yeri bir göreyim diye gittim. Gittiğimde orada birlikte yaşadığı yaşlı bir kişi Mamut Sican'ın yaşadığı evin duvarı üzerine yazılmış şiirleri bana gösterdi. Okuyunca gördüm ki aslında onlar Abduhalik'in "Uygurum" adlı şiiri ile Tukay'ın şiirleriymiş.

Yaşadığı devirde yasaklanan, Sovyetler Birliğinde izin verilmeyen bazı şiirler de Harbin'de basılmış Tukay eserleriydi. Pekin'de (Şimdiki Tian-an-men meydanında) bitpazarı vardı. Bu kitaplardan birini o pazardan satın aldım. Yaşlı Döngen'e "Sican bu kitabı mı okudu?" diye sorduğumda o, Sican'ın bu kitabı hiçbir zaman elinden düşürmediğini söylemişti.

Şunu demek istiyorum, Tukay'ın şiirleri sadece ediplerimiz ve şairlerimizin okuyup zevk aldığı eserlerden değil, o dönemde toplumumuzda birçok aydınımızın da elinden düşürmediği eserlerdendi. Yoksa Sican bir asker, Tukay'ın eserlerini okuyor derken insanın bunu tasavvur etmesi zordur. Bundan anlaşllıyor ki, Tukay'ın eserlerini o zamanki Uygur halkının kaderi hakkında kaygı duyan aydınlarımızın hemen hemen hepsi okuyormuş. Tukay'ın şiirleri onları çok etkilemiş. Bundan dolayı Uygur edebiyatındaki bu ilme yönelme, halkın kederini anlama, halkın istikbalini düşünme fikrinin kaynağı nereden geliyor diye sorulursa, Tukay'ın eserlerinden geliyor derim. Bundan önceki Klasik edebiyat çoğunlukla lirik eserler ve âşık-maşuk hakkındaki destanlar ile doluydu. Başka bir ifadeyle, yeni bir toplumsal anlayışı, ideolojiyi edebiyatımıza dâhil etmek, Yeni Uygur edebiyatının, Yeni Uygur şiirimizin bir özelliğidir bu özelliğin kazanılmasına sebep olan şey nedir derseniz, Abduhalik'in örneğinden, Lutpulla'nın örneğinden, Tukay'ın eserlerinden söz etmemiz gerekir. Demek istiyorum ki, Tukay'ın eserlerinin Uygur edebiyatı üzerindeki etkisi büyüktür. Uygur Klasik edebiyatının dilini hepimiz biliyoruz. Uygur Klasik edebiyatında Arapça, Farsça kelimeler çok kullanılır. Medrese eğitimi almadan, medresede 10-20 yıl okumadan, klasiklerimizin şiirlerini çok iyi anlamak birçok aydına da zor gelir. Bu şiir dilini halkın diline yakınlaştıran, şairleri halkın diliyle yazmaya yönlendiren de Tukay’dır. Çünkü kendi ana dilini sevmeyi, halkın dilinde şiir yazmayı rahmetli Teyipcan da söylemiştir. Abduhalik Uygur Sempozyumunda “Abduhalik Uygur'un dilindeki, Tukay'dan gördüğü şekilde, halkın diline yakınlığı, anadilini sevmeyi daha önceden anlaşmıș, daha önceden görmüş olsaydım, ben de şiirlerimde bu yolu takip ederdim." demiști Teyipcan. Rahmetli Teyipcan Eliyev "Benim şiirlerimde de medresenin tesiri var. Abduhalik Uygur'un şiirlerindekine benzeyen sade halk dili benim şiirlerimde eksik kalmış" demişti. Genelde Uygur şiirinde özelde Abduhalik Uygur'un ve Lutpulla 
Mutellip'in şiirlerindeki sadelik Tukay'dan gelmiştir diye düşünüyorum. Tukay ilk şiirlerinde klasik edebiyattan faydalanmıştır. Onun klasik dilde yazdığı birçok şiiri vardır. Sonra bu klasik dilden Tatar halk diline geçiş Tukay için büyük bir adım olur. İşte bu saf Tatar dili - halk dilinde şiir yazmayı bașlatmak Tukay'ın Tatar edebiyatına getirdiği bir yeniliktir. Bu bakımdan da bizim Yeni Uygur edebiyatımızın ilk temsilcilerinin dilinde Tukay'ın etkisi daha güçlü olmuştur diye düşünüyorum. Tukay'ın anadil hakkındaki şu şiirini okuyayım:

\section{TUĠAN TÍL}

İy tugan til, iy matur til, etkem - enkemniñ tili!

Dunyada köp nerse bildim sin tugan til arqill.

İyañ ilik bu til bilen enkem bişikte küylegen,

Annarı tunner boyı ebkem xikayat süylegen.

İy tugan til! Her vaqıtta yardemiñ birlen siniñ,

Kiçikkineden añlaşılg̉an şatlığım, qayg்ım miniñ.

İy tugaan til! Sinde bolgan iyañ ilik qılgan dugiam!

Yarlıqagill, dip, özim hem etkem - enkemni xudam!

\section{ANA DİLIM}

Ey anadilim, ey güzel dil, anamın, babamın dili!

Senin sayendedir dünyada öğrendiğim her şey.

Bu dil ile evvela, annem ninni söylemiş,

Sonrası, geceler boyu ninem masal anlatmış.

Ey anadilim! Her zaman yardımınla senin,

Küçüklükten beri hissederim sevincimi, kederimi.

Ey anadilim, seninleydi ettiğim ilk duam

Affet demiştim, beni, annemi ve babamı Tanrı'm.

$\mathrm{Bu}$ metin o dönemde birçok Uygur şairinin severek okuduğu bir şiir idi. Bizim Çağdaş şiirlerimizde de klasik şiir dilinden halk şiir diline geçişte birçok şairimiz Tukay'dan ilham almıştır demek bence abartı olmaz. Özetlersek, Yeni Uygur edebiyatı sanatçıları; gerek yenilik ideolojisinde olsun gerek halkçllı ideolojisinde olsun gerekse kendi milletinin geleceği, kederini düşünme ideolojisinde olsun Tukay'ı örnek almanın yanı sıra, şiir dilini halka yakınlaşmada da Tukay'dan ilham almışlardır. Tukay'ın Uygur edebiyatı üzerindeki etkisi çok büyüktür.

Yine eklemek istiyorum ki öğrencim Lutpulla, Abdulla Tukay'ın en sadık okuru, öğrencisiydi. Lutpulla’nın bilmediği Tukay şiiri yoktu. Ben birçok Tukay şiirinin en güzel nüshalarını Lutpulla'nın okumasından dinlemiştim. Ona "nereden öğrendin?" dediğimde "Gulca'da, Tatar mektebinde bize edebiyat dersi diye okutulan ders Tukay'ın eserleri idi" diye cevap verdi. Lutpulla'nın şiirlerindeki birkaç ince nokta edebiyatçılarımızın incelediği hususlardır. Ben Tukay’ı incelediğimde, Rusların Yişin adlı bir şairinin şiirlerini de okumuștum. O zaman "Vah! Bunlar Tukay'ın șiirlerine baya benziyor” diye düșünmüștüm. “Kim kimden öğrendi acaba?” diye baktım ki, Yişin, Tukay’dan sonra yaşamış. Tukay 1913 yılında vefat etmiş. Abduhalik Uygur'un ise Tukay’ı taklit ettiği şiiri 1921 yılında yazılmış. 
Yani Tukay'ın ölümünden sekiz yıl sonra yazılmış. Yişin'in Rusça şiirlerine bakınca da Tukay havası seziliyor. Bilhassa doğduğu köyünü överken, halkının güzel örf ve adetlerini betimlerken bu etkiyi açıkça görmek mümkündür. Ben, Yişin'in şiirlerini Burhan efendinin kızı İlçan'dan 1946 yılında yeniden basılan nüshasını iki günlük ödünç alıp okumuştum. Bu benzerliği sonra Teyipcan'a anlattım. "Eh, Yişin'i okumak gerekmiş. Biz Ruslarda Puşkin var, Lermontov var diyorduk, Tukay'a benzeyen bir Yişin varmış, çok benziyormuş. Tukay'ın şiirlerindeki birkaç özellik Yişin'in şiirlerinde de varmış" dedim. Teyipcan pek meraklandı. Sonrasında Teyipcan da Tukay'a derin bir sevgi duydu. Teyipcan'ın hastalığı ağırlaştığında yanına uğradık. Ertesi gün vefat etti. 0 zaman bizi görünce gözleri yaşarmıştı. Ben ona "Teyipcan dostum, ağlama, şairlerin ölüm karşısında Tukay gibi tavır alması gerek. Tukay'ın bir şiirini okuyayım mı?” dedim. 0 başını salladı:

\section{ŞAǴIYR}

Yıllar ötip, bara turgaç qartaysam - da,

Bukirim çığıp bitse - de, xelden taysam - da,

Köñlim minim yap - yaş qalır, hiç qartaymas;

Canım küçli bolıp qalır, xelden taymas.

Kökregimde minim şiġır utım savmı?!

Köterem min, qart bolsam-da, avır taunı;

Köñlimde kün haman ayaz - haman-da yaz:

Şag̉ıyr köñlinde qış bolmıy-da qar yaumıy.

Bulmamın, yoq, qartaysam-da, çın qart kibi,

Utırmam tik, yoq - bar tilek tiliy - tiliy;

İnmemin, xuday quşsa, miç başına.

Şig̈ırlerden kiler miniñ kirek cılı.

Cirlıy - cirlıy ölermen min ölgende-de,

Deşmiy qalmam gazırailni kökergende-de;

"Biz kitirmiz, siz qalarsız?!"-dip cırlamın,

Cesedimni tufraq birle kömgende-de.

\section{ŞAIR}

Yıllar geçip yaşlansam da,

Belim bükülüp, zayıf düşsem de,

Gönlüm benim genç kalır, hiç yaşlanmaz,

Ruhum kuvvet bulur, zayıf düşmez.

Göğsümde benim şiir ateşi varsa,

Taşırım yaşlansam da ağır dağı

Gönlüm ferah, mevsim artık yaz,

Şair gönlünde kış olmaz, kar da yağmaz,

Olamam, hayır, yaşlansam da gerçek yaşlı gibi,

Oturamam yalnız, hayal kurarak;

Kurulamam, Tanrı emretse bile, soba başına,

Şiirlerimden gelir bana gerekli sıcaklık.

Şiir söyleye söyleye ölürüm, vadem yetince,

Soru sormam Azrail'i görünce;

"Biz gideriz, siz kalırsınız!", derim şiirle,

Cesedim toprağa gömülürken de.

Ben şiiri okuduktan sonra, ağlayan Teyipcan gözyaşını silip güldü. "Dostum, ölüme karşı şairin Tukay gibi durması gerek. Şiir söyleyerek ölmüş işte, cesedi toprağa gömüldüğü zaman da dostlarına "Biz gideceğiz, siz kalacaksınız" demiş. "İşte böyle olmak gerek" dedim. Teyipcan gözyaşını yeniden silip güldü. Rahmetli ertesi gün vefat etti. Demek 
istiyorum ki şairlerimiz Teyipcan olsun, Lutpulla Mutellip olsun, Abduhalik Uygur olsun Abdulla Tukay'ın şiirlerini çok severek okuyorlar, hürmet ediyorlar. Çoğu ondan ilham almış, Tukay'dan öğrenmiştir. Şimdi bu yönden bakıldığında, halkın şairi, halkın kalbine yerleşmiştir. Halkın sevdiği bu unutulmaz şair Abdulla Tukay, Tatar halkının gurur duyduğu oğludur. Nerede olursa olsun, Tatarların olduğu her yerde "Tukay'ın Akşamı", "Tukay'ın Gecesi”, "Tukay’ın Ziyafeti” gibi ziyafetler, "Tukay Derneği” adlı topluluklar gerek Japonya'da gerek Yugoslavya'da gerek Avustralya'da olsun her yerde var. Tukay'ın şiirleri Kurtuluş'tan önce ilk kez Harbin'de basılmıștır. Harbin'de de Tukay adına sürekli edebi etkinlikler düzenleniyormuş. Ben bunu sonra muhabir olarak gittiğimde öğrendim. Şanhey'de yaşayan Tatarların arasına Kurtuluş'tan önce gitmiştim. Onların da Tukay adına kurulan dernekleri varmış. Bu toplumda da bütün Tatar halkı kendi manevi dünyası, manevi zenginliğini Tukay'dan almış, Tukay'ın ilhamıyla onu kendilerine "pir" sayıp hürmet etmişlerdir. Halk tarafından sevilen, halkın kalbinde derin yer edinmiş şair yalnız Tatar halkının şairi değil, Kazak halkının, Özbek halkının, Kırgız halkının, Uygur halkının da şairidir. İște bu halkların hemen hemen hepsi edebiyatlarında Tukay'ın yazdığı mısraları kendilerine miras olarak alıp, yeni edebiyatlarını geliştirmede Tukay'dan ilham almışlar, faydalanmışlar demek istiyorum. Uygur edebiyatında da öyle. Tukay'ı anmak yalnızca Tatar halkına mahsus bir anma günü değil, her milletin ortak anma günü olmalıdır. Bu sözü edilen halklar arasındaki medeni ilişkileri güçlendirmede, birbirlerine olan saygı ve sevginin artmasında büyük önem arz eder. Bizde halkların ittifakını güçlendirmenin türlü yolu vardır. Bana göre bu yolların en iyisi her bir halkın ediplerini anma toplantılarını ortak düzenlemektir. Kazak, Özbek, Kırgız, Uygur halklarına ait sanatçıların manevi dünyalarını, ruhi dünyalarını öğrenirsek, onlara olan sevgiyi güçlendirirsek sözü edilen halklar arasındaki bağlılığı da güçlendiririz diye düşünüyorum. Bundan dolayı bugün Tukay'ı anıyoruz, yarın Kazak șairlerinden Abay'ı anmamız ve yalnız Kazakların anma günü değil, tüm milletin ortak anma gününü yapmamı, hatta Çin halkının medeniyetini iyice anlamak için onların şairlerini anlamaya çalışmamız gerek. Li Bey, Dufu gibi birçok ünlü şâir sayesinde o milletin ruhi dünyası anlamak mümkündür. Milletler arasındaki milli birlikteliği güçlendirmede, birbirimizi derinden anlamada o milletin ünlü şair ve yazarlarını beraber anmanın iyi bir yol olduğunu düşünüyorum. İște bu sebeple "Bu toplantı iyi ki düzenlenmiş" diyerek memnuniyetimi bildiriyorum. Bundan sonra her yörenin bunun gibi toplantılarının sık sık düzenlenmesini ümit ediyorum. Hepinize teşekkürler!

\section{Kaynakça}

ÖZKAN, Fatma. (1994). Abdullah Tukay'ın Şiirleri, Inceleme-Metin-Aktarma. Ankara: Türk Kültürü Araştırmaları Enstitüsü Yayınları: 136, Seri: IV, N. 38.

İNAYET, Alimcan. (2007). Abdulhaluk Uygur ve Şiirleri. Ankara: Türk Dil Kurumu Yayınları. 